\title{
Adult Soft Tissue Sarcoma: A Prospective Observational Real-World Data
}

\author{
Shivashankara Mathighatta Shivarudraiah ${ }^{1}$ Sundaram Viswanath ${ }^{2}$ Suresh Pandalanghat ${ }^{2}$ \\ Dharmesh Soneji ${ }^{2}$ Manish Kumar ${ }^{2}$ Amol Patel ${ }^{2}$, Bupesh Guleria ${ }^{3}$ Nikhil Pathi ${ }^{2}$
}

Rahul Sud $^{2}$ Abhishek Pathak ${ }^{2}$ Anvesh Rathore²

${ }^{1}$ Department of Medical Oncology, Rajiv Gandhi Cancer Institute and Referral Centre, New Delhi, India

2Department of Medical Oncology, Army Hospital Research \& Referral, New Delhi, India

${ }^{3}$ Department of Medical Oncology, Basavatarakam Indo-American Cancer Institute and Research Centre, India

Address for correspondence Sundaram Viswanath, MBBS, MD, DM (Medical Oncology) Department of Medical Oncology, Army Hospital Research \& Referral, New Delhi, India (e-mail: viswanath1966@gmail.com).

Ind J Med Paediatr Oncol 2021;42:339-345.

\section{Abstract}

Keywords

- survival outcomes

- developing countries

- epidemiology

- India

- real-world data

- soft tissue sarcoma

- STS
Introduction There is a lacuna of prospective studies on soft tissue sarcoma (STS) from the Indian subcontinent in published literature.

Objectives We conducted this study to describe the clinical profile and outcomes of STS in North India.

Materials and Methods This is a single-center, prospective, observational study conducted from October 2017 to September 2019. All consecutive patients aged $\geq 18$ years with histopathological diagnosis of STS were enrolled. The study end points included overall response rate, progression-free survival (PFS), and overall survival (OS).

Results A total of 140 patients were included with a median duration of follow-up of 14 months (range: $1-25$ months). The median age of patients was 45 years. The median duration of symptoms before diagnosis was 5 months (range: 1-18 months). The most common histopathologic subtype was undifferentiated pleomorphic STS (22\%). Of 105 localized patients, 21 received neoadjuvant therapy with external beam radiotherapy and/or doxorubicin-based chemotherapy and reported partial response in $38 \%$ $(8 / 21)$ of the patients; the remaining $62 \%(13 / 21)$ of the patients had stable disease. Neoadjuvant therapy resulted in nonsignificantly higher complete resection rates with relative risk of $2.37(p=0.19)$. Of the remaining 35 metastatic STS patients, 31 received chemotherapy and reported partial response in $39.1 \%(n=9 / 23)$, stable disease in $30.4 \%$ $(n=7 / 23)$, and disease progression in $30.4 \%(n=7 / 23)$ of the patients. For localized STS patients, 1 -year disease-free survival (DFS) and OS rates were $87.6 \pm 3.5$ and 95.3 $\pm 2.3 \%$, respectively. The median OS for metastatic STS patients was 23.90 months (95\% confidence interval [Cl]: 7.43-40.36). Among metastatic STS, median OS was not reached for those who underwent curative resection versus 12.66 months (95\% Cl: 9.28-16.04) for those who received systemic therapy alone.

Conclusion Median age of 45 years is a decade earlier than seen in the Western population. Neoadjuvant therapy improved complete resection rates, though it was statistically nonsignificant. Curative resection among metastatic STS patients improves survival.
DOI https://doi.org/ $10.1055 / \mathrm{s}-0041-1731856$ ISSN 0971-5851 (c) 2021. Indian Society of Medical and Paediatric Oncology. This is an open access article published by Thieme under the terms of the Creative Commons Attribution-NonDerivative-NonCommercial-License, permitting copying and reproduction so long as the original work is given appropriate credit. Contents may not be used for commercial purposes, or adapted, remixed, transformed or built upon. (https://creativecommons.org/licenses/by-nc-nd/4.0/).

Thieme Medical and Scientific Publishers Private Ltd. A-12, Second Floor, Sector -2, NOIDA -201301, India 


\section{Introduction}

Soft tissue sarcomas (STSs) constitute around $1 \%$ of all cancer types and include a heterogeneous group of more than 50 histopathological subtypes. ${ }^{1,2}$ STS can arise from the mesenchymal tissue of any anatomical site. The clinical presentation of STS patients may have various symptom complexes depending on the location of origin, the aggressiveness of the disease, and the extent of spread. The management of resectable STS primarily involves surgery. The addition of perioperative radiotherapy and/or chemotherapy improves disease-free survival (DFS) and overall survival (OS)., ${ }^{3,4}$ The multimodality approach depends on patient characteristics, anatomical site, histopathological subtype, stage, and available resources. ${ }^{5}$ Despite these advances, the overall 5 -year survival probability is around $50 \%{ }^{6}$

Similar to other cancers, even among sarcomas, there appear to be significant ethnic and racial influences on clinical profile (such as age, stage at presentation, and tumor grade) and outcomes. ${ }^{78}$ In addition, in developing countries, due to lack of health awareness, limited access to health and insufficient information among primary care providers may result in delayed diagnosis. This delay in diagnosis may result in advanced disease status and poor outcomes. There is a paucity of prospective studies in STS from the Indian subcontinent and low-to-middle-income countries, as most of the previous studies in the published literature are retrospective case series. ${ }^{9-12}$ The present study was done prospectively to gain insight into the disease patterns and outcomes of STS in the Indian setup. Understanding STS patients' profile is essential in improving care for sarcoma patients and also for further research, to emphasize the significance of multidisciplinary management, and to raise awareness about the importance of STS collaborative network group in India.

\section{Materials and Methods}

This prospective, observational study was conducted from October 2017 to September 2019 at a tertiary care center in India. In this study, we had planned to include total 100 patients of STS, considering $5 \%$ level of significance $(\alpha)$, $7 \%$ margin of error (L), taking 1-year mortality of $13 \%,{ }^{7}$ and assuming 10\% drop-outs/attrition/lost to follow-up. Patients aged 18 years and above, with histologically proven STS, were included in the study. Patients with recurrent disease, Ewing's sarcoma (EWS), gastrointestinal stromal tumors, and sarcomas arising from the bone were excluded from the study.

Baseline assessment included demographical data, clinical history, physical examination, histopathology on core-needle biopsy, or surgical sample. For staging, contrast-enhanced computed tomography (CECT)/magnetic resonance imaging (MRI) for the primary tumor and CECT chest or positron emission tomography (PET)/CT for metastatic workup were done. Histopathological subtyping and grading were done as per the World Health Organization classification and Federation Nationale des Centres de Lutte Contre le Cancer (FNLCC) grading system, respectively. ${ }^{2,13,14}$ The staging was done as per the American Joint Committee on Cancer eighth edition tumor-node-metastasis staging. ${ }^{15}$
In the case of localized and resectable oligometastatic STS, patients were treated with surgery. Only lung-limited metastases were considered for resection. The local multidisciplinary team determined the resectability of lung metastases after discussion in the tumor board. Perioperative therapy with radiotherapy \pm chemotherapy was considered as per the standard guidelines and/or tumor board decision. Chemotherapy in the adjuvant or neoadjuvant setting included doxorubicin $25 \mathrm{mg} / \mathrm{m}^{2}$ for 3 days with ifosfamide $3 \mathrm{~g} / \mathrm{m}^{2}$ for 3 days once every 21 days except in rhabdomyosarcoma, in whom vincristine, actinomycin D, and cyclophosphamide were used. In the metastatic setting, depending on the treating physician's discretion, doxorubicin $25 \mathrm{mg} / \mathrm{m}^{2}$ for 3 days with or without ifosfamide 2 to $3 \mathrm{~g} / \mathrm{m}^{2}$ for 3 days once every 21 days was used based on fitness, age, and tumor burden.

In the neoadjuvant setting, response assessment was done after 4 weeks of completion of radiotherapy or after three cycles of chemotherapy. The response assessment was done using the RECIST version 1.1 response criteria.

At the end of therapy, CT/MRI of the primary site and CT chest were done to document disease status. Patients who have achieved remission or stable disease were followed-up once in every 3 months with clinical evaluation. CT/MRI of the primary site and $\mathrm{CT}$ chest were done in every 6 months, in the first 2 years, and then annually in surgically treated patients. Patients treated with palliative chemotherapy and those who achieved at least stable disease were followed-up with repeat imaging in every 3 months or at clinical progression. For analysis of results, patients who belonged to stage IA to Stage IIIB were grouped under localized STS cohort and those with lymph-nodal or distant metastases under stage IV or metastatic disease. DFS was defined as the time from the date of biopsy to the time of disease recurrence or death, whichever occurred first. Progression-free survival (PFS) was defined as the time from the date of biopsy to the time of progression or death, whichever occurred first. OS was defined as the time from the date of biopsy to the time of death due to any cause. Data regarding the recurrence/progression of the disease and survival were noted. The study was conducted after due approval from the Institutional ethics committee, Army Hospital (R \& R), Delhi Cantt (Institutional Ethical Committee Rge no: 99/2017, Date: October 24, 2017). The procedures followed were in accordance with the ethical standards of the responsible committee on human experimentation (institutional or regional) and with the Helsinki Declaration of 1964, as revised in 2013. All patients provided written informed consent for participating in this study.

\section{Statistical Analysis}

Data were analyzed with SPSS software version 25.0, Released 2017, SPSS for Windows, SPSS Inc., Chicago, Illinois, United States. Descriptive statistics were used for defining the study population and baseline disease characteristics. A Chi-square test was used for the analysis of categorical variables in the study. Kaplan-Meier curves were plotted for survival analyses. A log-rank test was used to compare the data in different groups. 


\section{Results}

A total of 140 patients of histologically proven STS were included in the study. The median age of the patients was 45 years (range: $18-84$ years), and $54.3 \%(n=76)$ were male. The median duration of symptoms before presentation was 5 months (range: 1-18 months). Extremity sarcoma constituted the most common type constituting $54.3 \%$, followed by trunk sarcoma (17.86\%), retroperitoneal sarcoma (14.29\%), thoracic and abdominal visceral sarcomas (9.29\%), and head-and-neck sarcomas (4.29\%). The most common presentation was swelling seen in $70 \%(n=99)$ of the patients; the swelling was painless in $58.5 \%(n=82)$ and painful in $12.5 \%$ $(n=17)$ of the patients. Other complaints at presentation were abdominal pain in $15 \%$ of the patients and weight loss, constitutional symptoms, dry cough, breathlessness, radiculopathy, and bleeding per vagina, each in $<10 \%$ of the patients. Thirty-five patients had lymph node or distant metastases. The most common site of distant metastases was lungs as seen in $65 \%$ of the patients ( $n=23 / 35$ ), followed by liver in $25 \%$ of the patients $(n=9 / 35)$. Other sites included pleura (8.5\%), spine (8.5\%), musculoskeletal (5.6\%), and brain (2.8\%). The most common histopathologic subtypes were undifferentiated pleomorphic STS (22\%), followed by leiomyosarcoma (19\%) and synovial sarcoma (16\%). The baseline demographic and clinical characteristics of the study population are summarized in - Table 1 .

Translocations were assessed in $10 \%(n=14)$ of the patients. Of these 11 suspected synovial sarcoma patients, 10 tested positive for X: 18 translocation. In another two probable myxoid liposarcoma patients, one turned out positive for $\mathrm{t}$ $(12 ; 16)(q 13 ; p 11)$, that is, TLS-CHOP. Furthermore, one round blue cell sarcoma of the abdomen had $t(11 ; 22)(p 13 ; q 12)$, that is, EWS-Wilms' tumor 1, conforming to desmoplastic small round cell tumor. Consequently, out of 14 patients, accurate subtyping of STS could be done in 12 patients with the molecular studies. The FNLCC grading was available in $88.6 \%$ of the patients $(n=124) ; 35 \%(n=49)$ of the patients had grade 3 , followed by grade 2 in $34.3 \%(n=48)$, and grade 1 in $19.3 \%(n=27)$ of the patients. In the remaining $11.4 \%$ of the patients $(n=16)$, FNLCC grading could not be evaluated due to various reasons including missing data, insufficient test material, and inapplicability to certain histopathological subtypes such as alveolar STS, angiosarcoma embryonal, and alveolar rhabdomyosarcoma. ${ }^{15}$

\section{Treatment Patterns}

Of 105 patients with localized disease, 92 patients had wide local excision, 5 patients required amputation, and, in 8 patients, tumor was not resectable. Among 97 resected patients, 21 patients received neoadjuvant therapy, 58 patients received adjuvant therapy, and 26 patients underwent surgery alone. Of 21 patients receiving neoadjuvant therapy, 10 patients received radiotherapy (preoperative radiotherapy $50 \mathrm{~Gy}$ with $2 \mathrm{~Gy} / \#$ over 25 days) and 8 patients received chemotherapy (doxorubicin $25 \mathrm{mg} / \mathrm{m}^{2}$ for 3 days + ifosfamide $2-3 \mathrm{~g} / \mathrm{m}^{2}$ for 3 days in a 3-week cycle). Three patients received both radiotherapy and chemotherapy before surgery. Fifty-eight patients received adjuvant therapy in the form of external beam radiotherapy $(n=28)$ or doxorubicin-based chemotherapy $(n=16)$ or both $(n=14)$. Of the 21 patients receiving neoadjuvant therapy, partial response was seen in $38 \%(n=8 / 21)$ of the patients, and the remaining $62 \%(n=13 / 21)$ had stable disease. In the neoadjuvant group, $90.5 \%$ of the patients $(n=19 / 21)$ had complete resection (R0) as compared with $76.3 \%$ of the patients ( $n=58 / 76)$ among those who underwent upfront surgery. The relative risk of having incomplete resection in upfront surgery cohort compared with that of postneoadjuvant therapy cohort was 2.37 (95\% confidence interval [CI]: 0.599.4; $p=0.19$ ).

Among 35 metastatic STS patients, 31 patients received chemotherapy; majority $(65.7 \%, n=23 / 35)$ received it as palliative therapy and $39.7 \%(n=8 / 35)$ of the patients were treated with curative intent (with surgery + chemotherapy [doxorubicin $25 \mathrm{mg} / \mathrm{m}^{2}$ for 3 days + ifosfamide $2-3 \mathrm{~g} / \mathrm{m}^{2}$ for 3 days in a 3-week cycle]) in adjuvant setting, following resection of both primary tumor and metastases. Of 23 patients receiving palliative chemotherapy, partial response was seen in $39.1 \%(n=9 / 23)$ and stable disease in $30.4 \%(n=7 / 23)$ of the patients; disease progression was reported in $21.8 \%$ ( $n=$ $7 / 23$ ) of the patients.

\section{Survival Outcomes}

Among localized STS patients, 36 patients had a recurrence or progressive disease. These were 16 local recurrences and 18 distant metastases. And also, six deaths $(5.7 \%, n=6 / 105)$ had occurred in localized STS patients. In metastatic STS patients, there were $14(40 \%, n=14 / 35)$ deaths and $23(65.7 \%$, $n=23 / 35)$ patients had disease progression.

After the median follow-up of 14 months (1-25 months), the 1 -year PFS and OS rates were $75.8 \pm 3.1$ and $87.4 \pm 3.1 \%$, respectively. For localized STS patients, the median DFS was 20.93 months (95\% CI: 18.09-23.77); 1-year DFS and OS rates were $87.6 \pm 3.5$ and $95.3 \pm 2.3 \%$, respectively. For metastatic STS patients, the median PFS and OS were 9.83 months (95\% CI: 4.8-14.85) and 23.90 months (95\% CI: 7.43-40.36), respectively. One-year PFS and OS rates were $36.53 \pm 9.8$ and $61.97 \pm 9.1 \%$, respectively ( - Fig. 1 ).

In stage-IV STS patients $(n=35)$ and those who had curative-intent/definitive therapy $(n=8)$, the median PFS was 20.43 months (95\% CI: 5.83-35.02) as compared with 6.83 months (95\% CI: 4.92-8.74) in those in palliative therapy cohort $(n=27)$. The median OS was not reached in the curative intent therapy cohort, whereas it was 12.66 months (95\% CI: 9.28-16.04) in the palliative therapy cohort, as shown in - Figs. $2 \mathrm{~A}$ and $\mathbf{B}$.

\section{Discussion}

STSs are a rare and heterogeneous group of malignant tumors arising from the mesenchymal tissue. As per cancer statistics in the United States, the incidence of STSs is approximately $0.72 \%,{ }^{1}$ whereas incidence data on STSs in India are unknown as studies in published literature are limited to the retrospective institutional case series. ${ }^{9-12}$ 
342 Soft Tissue Sarcoma Shivashankara et al.

Table 1 Baseline demographic and clinical characteristics of the study population

\begin{tabular}{|c|c|}
\hline Parameter & Value \\
\hline Age in years, median (range) & $45(18-64)$ \\
\hline Male, $n(\%)$ & $76(54.3)$ \\
\hline Female, $n(\%)$ & $64(45.7)$ \\
\hline Duration of symptoms in months, median (range) & $5(1-18)$ \\
\hline \multicolumn{2}{|l|}{ Type of sarcoma, $n(\%)$} \\
\hline Extremity sarcoma & $76(54.3)$ \\
\hline Trunk sarcoma & $25(17.86)$ \\
\hline Retroperitoneal sarcoma & $20(14.29)$ \\
\hline Thoracic and abdominal visceral sarcoma & $13(9.29)$ \\
\hline Head and neck sarcoma & $6(4.29)$ \\
\hline \multicolumn{2}{|l|}{ Histopathologic subtypes } \\
\hline Undifferentiated pleomorphic STS & $31(22.1)$ \\
\hline Leiomyosarcoma & $26(18.6)$ \\
\hline Synovial sarcoma & $23(16.4)$ \\
\hline Liposarcoma & $21(15)$ \\
\hline MPNST & $12(8.6)$ \\
\hline Fibrosarcoma & $8(5.7)$ \\
\hline Rhabdomyosarcoma & $5(3.6)$ \\
\hline Angiosarcoma & $4(2.9)$ \\
\hline Others & $10(14)$ \\
\hline \multicolumn{2}{|l|}{ Tumor characteristics, $n$ (\%) } \\
\hline \multicolumn{2}{|l|}{ T stage } \\
\hline T1 & $20(14.29)$ \\
\hline $\mathrm{T} 2$ & $54(38.57)$ \\
\hline T3 & $35(25)$ \\
\hline $\mathrm{T} 4$ & $31(22.14)$ \\
\hline \multicolumn{2}{|l|}{ N stage } \\
\hline NO & $132(94.29)$ \\
\hline N1 & $8(5.71)$ \\
\hline \multicolumn{2}{|l|}{ M stage } \\
\hline M0 & $109(77.80)$ \\
\hline M1 & $31(22.20)$ \\
\hline \multicolumn{2}{|l|}{ FNLCC grade, $n(\%)$} \\
\hline Grade 1 & $27(19.30)$ \\
\hline Grade 2 & $48(34.30)$ \\
\hline Grade 3 & $49(35.00)$ \\
\hline Grade unknown (Gx) & $16(11.40)$ \\
\hline \multicolumn{2}{|l|}{ Cancer stage, $n(\%)$} \\
\hline IA & $6(4.29)$ \\
\hline IB & $18(12.86)$ \\
\hline II & $8(5.71)$ \\
\hline IIIA & $46(32.86)$ \\
\hline IIIB & 27 (19.29) \\
\hline IV & $35(25)$ \\
\hline
\end{tabular}

Abbreviations: FNLCC, Federation Nationale des Centres de Lutte Contre le Cancer; MPNST, malignant peripheral nerve sheath tumor; STS, soft tissue sarcoma. 

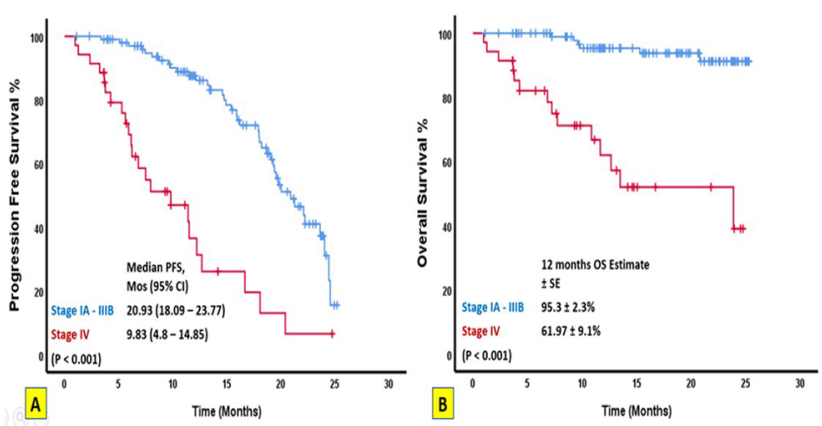

Fig. 1 Kaplan-Meier estimate of progression-free survival (A) and overall survival (B) between localized soft tissue sarcoma (stage Istage IIIB) and metastatic soft tissue sarcoma (stage IV). Cl, confidence interval; PFS, progression-free survival; OS, overall survival; SE, standard error.
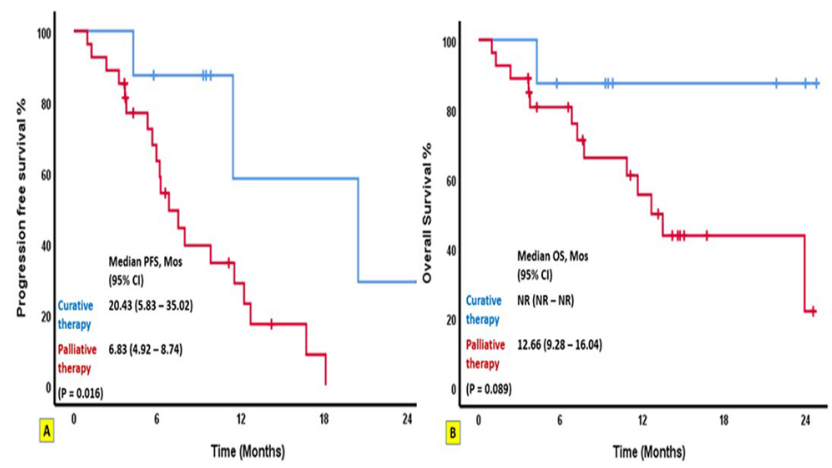

Fig. 2 Kaplan-Meier estimate of progression-free survival (A) and overall survival (B) among metastatic soft tissue sarcoma patients by type of therapy. $\mathrm{Cl}$, confidence interval; NP, not reported; PFS, progression-free survival; OS, overall survival, Mo, months.

STS incidence increases with age, with the reported median age in Western literature falling in the sixth decade. ${ }^{16-18}$ In our study, the median age was 45 years, which was comparable to that of other studies from different parts of India, as shown in - Table 2. The median age in the Indian subcontinent is a decade earlier than that in the developed countries. This early occurrence may be due to differing age spectrums of the population in developed countries and India, as a significant proportion of the Indian population is young. A slight male preponderance with a male-to-female ratio of $1.4: 1$ is reported similar to other studies. ${ }^{22}$

Fifty percent of the patients had symptoms for more than 5 months before diagnosis. Painless nature of swelling compounded with a lack of health awareness and limited access to health care results in delayed diagnosis of these tumors. ${ }^{23}$ Besides, lack of health expertise among primary health care providers to accurately differentiate sarcomas from more common benign soft-tissue tumors may result in an inadvertent excision and further delay in referral. This delay in diagnosis may hamper the management of the disease and may affect limb salvage and patient survival. ${ }^{10}$ Clinical presentation and management also depend on the anatomical site of origin. In our study, extremity was the most common site, followed by trunk (chest and abdominal wall) and retroperitoneum. The study by Shukla and Deo also reported extremity as the most common followed by chest and trunk. On the other hand, Rastogi et al reported extremity followed by retroperitoneum as the most frequent sites. ${ }^{12}$

Being a rare tumor with more than 50 subtypes makes histopathological subtyping difficult. STSs are often labeled high-grade sarcomas or undifferentiated pleomorphic sarcomas when specific lines of differentiation are not identified. ${ }^{2}$ In our study, undifferentiated pleomorphic sarcoma was the most common histopathological subtype, followed by leiomyosarcoma and synovial sarcoma. On the other hand, most Indian studies reported synovial sarcoma as the most common histopathological type, as shown in - Table 2. ${ }^{9,10,12}$ However, with standardization of diagnostic criteria and extended immunohistochemistry, some of the undifferentiated pleomorphic sarcomas can be reclassified into specific subtypes. ${ }^{24}$

Furthermore, translocation studies may sort out a few discrepancies, as shown in the GENSARC study. ${ }^{25}$ In our study, at least in 12 cases (i.e., $9 \%$ ), translocation studies were reclassified to a specific subtype. As discussed above, histopathological subtyping is complex and has poor reproducibility. Several simple histopathological grading systems have been proposed which also provide a better prognostic model. Most commonly used and validated in various studies is the three-tier FNLCC grading system. ${ }^{14,26}$

Management of localized STSs involves a multidisciplinary approach, with surgery being the important modality of therapy. Radiotherapy or chemotherapy in a perioperative setting improves outcomes in tumors of size $\geq 5 \mathrm{~cm}$, deep seated, or high grade. ${ }^{27}$ Preoperative therapy is associated with increased ease of resection, decreased local recurrence, reduced late toxicity, and a trend toward improved survival outcomes. ${ }^{3,28,29}$ Our study was not randomized, and neoadjuvant therapies were considered in relatively advanced tumors on a case-to-case basis after tumor board discussions. We observed nonsignificantly higher complete resection rates in the neoadjuvant cohort.

In our study, 1 -year PFS and OS rates were 75.8 and $87.4 \%$, respectively, for the overall cohort. In a large retrospective study in Germany based on 24,753 patients' survival data, the reported median survival was 5.83 years and a 1-year survival probability was $77 \%{ }^{30}$ For localized STS patients, the median DFS estimate was 20.93 months, with 1 -year DFS and OS rates being 87.6 and $95.3 \%$, respectively. Bajpai et al reported that 3-year PFS and OS were 48 and 64\%, respectively. The outcomes in other Indian studies are shown in - Table 2. The variation in survival outcomes reflects the study population's heterogeneity, such as stage, histological subtypes, grades, and use of different treatment options.

Among metastatic STS patients, the majority received systemic chemotherapy therapy. Still, $25 \%$ of the patients also underwent curative resection surgery of both locoregional disease and metastases followed by systemic therapy. In the METASARC observational study, $48.6 \%$ of the patients received definitive therapy for locoregional disease and metastases. ${ }^{31}$ In our study, the majority of the patients had unresectable metastases. 
Table 2 Key adult STS studies from India in published literature

\begin{tabular}{|c|c|c|c|c|c|c|}
\hline $\begin{array}{l}\text { Author, } \\
\text { Institution } \\
\text { (year of study) }\end{array}$ & Type of study & $\begin{array}{l}\text { Sample size/ } \\
\text { type of STS }\end{array}$ & $\begin{array}{l}\text { Median age } \\
\text { (years)/M:F }\end{array}$ & $\begin{array}{l}\text { Most common histo- } \\
\text { pathology, (\%) }\end{array}$ & $\begin{array}{l}\text { Median } \\
\text { follow-up } \\
\text { (mo) }\end{array}$ & Outcomes \\
\hline $\begin{array}{l}\text { Bansal et al, } \\
\text { CRI, Dehradun } \\
(2018)^{19}\end{array}$ & $\begin{array}{l}\text { Retrospective } \\
\text { analysis }\end{array}$ & $\begin{array}{l}\text { 43/extremity } \\
\text { sarcoma }\end{array}$ & 48/1.8:1 & $\begin{array}{l}\text { 1. Pleomorphic } \\
\text { sarcoma, }(20.9 \%) \\
2 . \text { Synovial sarcoma, } \\
16.2 \%\end{array}$ & 47 & $\begin{array}{l}\text { At median fol- } \\
\text { low-up, EFS: } 41.49 \% \\
\text { and OS: } 47.64 \% ;\end{array}$ \\
\hline $\begin{array}{l}\text { Bajpai et al, } \\
\text { TMH, Mumbai } \\
(2018)^{9}\end{array}$ & $\begin{array}{l}\text { Retrospective } \\
\text { analysis }\end{array}$ & $\begin{array}{l}\text { 189/extremity } \\
\text { sarcoma }\end{array}$ & $41 / 1.7: 1$ & $\begin{array}{l}\text { 1. Synovial sarcoma } \\
(31 \%)\end{array}$ & 51 & $\begin{array}{l}\text { 3-year EFS: 48\%, and } \\
\text { OS:64\%; }\end{array}$ \\
\hline $\begin{array}{l}\text { Gupta et } \\
\text { al, Wenlock } \\
\text { Hospital, } \\
\text { Mangalore } \\
(2009)^{20}\end{array}$ & $\begin{array}{l}\text { Retrospective } \\
\text { study }\end{array}$ & 51/all types & $\begin{array}{l}\text { Fourth and Fifth } \\
\text { decades/1.36:1 }\end{array}$ & $\begin{array}{l}\text { 1. Liposarcoma } \\
\text { (17.5\%) } \\
\text { 2. Leiomyosarcoma } \\
(15.7 \%)\end{array}$ & NR & NR \\
\hline $\begin{array}{l}\text { Badanale et al, } \\
\text { TMH, Mumbai } \\
(2009)^{11}\end{array}$ & $\begin{array}{l}\text { Histopathologic } \\
\text { review of } \\
\text { biopsies }\end{array}$ & $\begin{array}{l}\text { 328/trunk and } \\
\text { extremity STS }\end{array}$ & 40.5/1.7:1 & $\begin{array}{l}\text { 1. Synovial sarcoma } \\
\text { 16\% } \\
\text { 2. Leiomyosarcoma } \\
11.3 \%(45 / 328)\end{array}$ & NR & NR \\
\hline $\begin{array}{l}\text { Rastogi et al } \\
\text { AllMS, New } \\
\text { Delhi, }(2018)^{12}\end{array}$ & $\begin{array}{l}\text { Retrospective } \\
\text { analysis of } \\
\text { prospective } \\
\text { database }\end{array}$ & $\begin{array}{l}\text { 156/advanced } \\
\text { STS }\end{array}$ & $\begin{array}{l}41 \\
(17-77) / 1.73: 1\end{array}$ & $\begin{array}{l}\text { 1. Synovial sarcoma } \\
(22 \%) \\
\text { 2. MPNST (16\%), }\end{array}$ & 13 months & $\begin{array}{l}\text { Median OS: } 16 \\
\text { months }\end{array}$ \\
\hline $\begin{array}{l}\text { Shukla and } \\
\text { Deo AllMS, } \\
\text { New Delhi, } \\
2011^{10}\end{array}$ & $\begin{array}{l}\text { Retrospective } \\
\text { analysis of } \\
\text { prospective } \\
\text { database }\end{array}$ & 300/all types & $\begin{array}{l}40.6 \\
(10-85) / 2: 1\end{array}$ & $\begin{array}{l}\text { 1. Synovial sarcoma } \\
(15 \%) \\
\text { 2. MFH (13.9\%). }\end{array}$ & NR & NR \\
\hline $\begin{array}{l}\text { RGCl, Delhi } \\
\text { Tiwari et al, } \\
2017^{21}\end{array}$ & $\begin{array}{l}\text { Retrospective } \\
\text { study }\end{array}$ & $\begin{array}{l}\text { 112/extremity } \\
\text { and trunk }\end{array}$ & $\begin{array}{l}\text { Approximately } \\
50 \% \text { were less } \\
\text { than } 50 \text { years }\end{array}$ & $\begin{array}{l}\text { 1. Synovial sarcoma } \\
(23.2 \%) \\
\text { 2. UPS }(22.3 \%)\end{array}$ & NR & $\begin{array}{l}\text { 5-year EFS:42.1\%, } \\
\text { OS: } 73.1 \%\end{array}$ \\
\hline
\end{tabular}

Abbreviations: AlIMS, all India Institute of Medical science; CRI, Cancer Research Institute; EFS, event free survival; F, female; M, male; MFH, malignant fibrous histiocytoma; MPNST, malignant peripheral nerve sheath tumor; NR, not reported; OS, overall survival; RGCl, Rajiv Gandhi Cancer Institute; STS, soft tissue sarcoma; TMH, Tata Memorial Hospital; UPS, undifferentiated Pleomorphic sarcoma.

The presence of metastases predicts a dismal outcome in STS, mainly if resection of both primary and metastases is not feasible. The median PFS and OS of metastatic STS patients in our study were 9.83 months (95\% CI: 4.814.85 ) and 23.90 months (95\% CI: 7.43-40.36), respectively. A retrospective analysis of 156 advanced STS patients from North India reported a median OS of 16 months. ${ }^{12}$ Another study from the United States of 363 metastatic STS patients reported a median OS of 22 months and 17 months among treated and untreated patients, respectively. ${ }^{18}$ The basis of a good outcome in our metastatic patients may be a result of improved outcomes in $25 \%$ of these patients who underwent complete resection. Among those who underwent curative resection, median OS was not reached as compared with 12.33 months among those who received palliative therapy alone. In the METASARC study, those who received locoregional therapy/definitive therapy had a better probability of survival. ${ }^{31}$ Similarly, the European Organization for Research and Treatment of Cancer Soft Tissue and Bone Sarcoma Group reported a 38\% 5-year OS among 255 STS patients who underwent metastasectomy. ${ }^{32}$

\section{Strengths and Limitations}

Our study being prospectively conducted helps to understand the spectrum of STS patients managed at a tertiary care center.
It highlights the difficulties in accurate histological subtyping in a real-world setting. It acts as a stepping stone for further studies in a neoadjuvant setting and oligometastatic STS. The limitations of this study include the retrospective design, single-center study nature, and small sample size with a short follow-up; randomized trials with long-term follow-up are needed to delineate differences in the outcomes better.

\section{Conclusion}

The median age of STS patients is a decade earlier than that in developed countries. Undifferentiated pleomorphic STS was the most frequent histological type. The median OS was not reached for localized STS patients, with 1-year OS rate being $95.3 \pm 2.3 \%$. The median OS for metastatic STS patients was 23.90 months (95\% CI: 7.43-40.36). Among metastatic STS, the median OS was not reached for those who underwent curative resection versus 12.66 months (95\% CI: 9.28$16.04)$ for those who received systemic therapy alone. STS requires a dedicated multidisciplinary team for appropriate management. To advance sarcoma care and research in India, multiple institutes should cooperate and form the Indian sarcoma network group.

\section{Conflicts of Interest}

There are no conflicts of interest to declare. 


\section{References}

1 Siegel RL, Miller KD, Jemal A. Cancer statistics, 2020. CA Cancer J Clin 2020;70(1):7-30

2 Fletcher CDM, Bridge JA, Hogendoorn PC, Mertens F, eds. WHO Classification of Tumours of Soft Tissue and Bone. 4th ed. Lyon, France: IARC Publications; 2013

3 Albertsmeier M, Rauch A, Roeder F, et al. External beam radiation therapy for resectable soft tissue sarcoma: a systematic review and meta-analysis. Ann Surg Oncol 2018;25(3):754-767

4 Pervaiz N, Colterjohn N, Farrokhyar F, Tozer R, Figueredo A, Ghert M. A systematic meta-analysis of randomized controlled trials of adjuvant chemotherapy for localized resectable soft-tissue sarcoma. Cancer 2008;113(3):573-581

5 Dangoor A, Seddon B, Gerrand C, Grimer R, Whelan J, Judson I. UK guidelines for the management of soft tissue sarcomas. Clin Sarcoma Res 2016;6:20

6 Ferrari A, Sultan I, Huang TT, et al. Soft tissue sarcoma across the age spectrum: a population-based study from the Surveillance Epidemiology and End Results database. Pediatr Blood Cancer 2011;57(6):943-949

7 Nandra R, Hwang N, Matharu GS, Reddy K, Grimer R. One-year mortality in patients with bone and soft tissue sarcomas as an indicator of delay in presentation. Ann R Coll Surg Engl 2015;97(6):425-433

8 Martinez SR, Robbins AS, Meyers FJ. Bold RJ, Khatri VP, Goodnight JE Jr. Racial and ethnic differences in treatment and survival among adults with primary extremity soft-tissue sarcoma. Cancer 2008;112(5):1162-1168

9 Bajpai J, Khanna N, Vora T, et al. Analysis of bone and soft-tissue sarcomas registered during the year 2012 at Tata Memorial Hospital, Mumbai, with clinical outcomes. Indian J Cancer 2018;55(1):37-44

10 Shukla NK, Deo SV. Soft tissue sarcoma-review of experience at a tertiary care cancer centre. Indian J Surg Oncol 2011;2(4):309-312

11 Badanale R, Rekhi B, Jambhekar NA, et al. Histopathologic review of 400 biopsies and resection specimens of trunk and extremity-based soft tissue tumors. Indian J Cancer 2017;54(2):401-408

12 Rastogi S, Sharma A, Aggarwal A, et al. Outcomes of advanced soft tissue sarcoma from dedicated medical oncology sarcoma clinic in North India and evaluation of the respective model. JCO 2018;36(suppl 15) :e23561

13 Trojani M, Contesso G, Coindre JM, et al. Soft-tissue sarcomas of adults; study of pathological prognostic variables and definition of a histopathological grading system. Int J Cancer 1984;33(1):37-42

14 Guillou L, Coindre JM, Bonichon F, et al. Comparative study of the National Cancer Institute and French Federation of Cancer Centers Sarcoma Group grading systems in a population of 410 adult patients with soft tissue sarcoma. J Clin Oncol 1997;15(1):350-362

15 Amin MB, Edge S, Greene F, et al. eds. AJCC Cancer Staging Manual. 8th ed. Switzerland: Springer Nature; 2017
16 Burningham Z, Hashibe M, Spector L, Schiffman JD. The epidemiology of sarcoma. Clin Sarcoma Res 2012;2(1):14

17 Honoré C, Méeus P, Stoeckle E, Bonvalot S. Soft tissue sarcoma in France in 2015: Epidemiology, classification and organization of clinical care. J Visc Surg 2015;152(4):223-230

18 Chen C, Borker R, Ewing J, et al. Epidemiology, treatment patterns, and outcomes of metastatic soft tissue sarcoma in a community-based oncology network. Sarcoma 2014:145764

19 Bansal S, Das K, Jain N, et al. Retrospective analysis of spectrum of presentation and treatment outcome in extremity sarcomas: a single-centre experience. Sarcoma 2018;2018:4350634

20 Gupta A, Rao HK, Gupta S. The incidence of soft tissue sarcoma in Dakshina Kannada: study in a District Government Hospital. Indian J Surg 2009;71(1):10-14

21 Tiwari A, Shah S, Sharma AK, et al. Prognostic factors in Indian patients operated for soft tissue sarcomas-a retrospective cross-sectional analysis. Indian JSurg Oncol 2017;8(2):128-135

22 Hui JY. Epidemiology and etiology of sarcomas. Surg Clin North Am 2016;96(5):901-914

23 George A, Grimer R. Early symptoms of bone and soft tissue sarcomas: could they be diagnosed earlier. ? Ann R Coll Surg Engl 2012;94(4):261-266

24 Fletcher CD, Gustafson P, Rydholm A, Willén H, Akerman M. Clinicopathologic re-evaluation of 100 malignant fibrous histiocytomas: prognostic relevance of subclassification. J Clin Oncol 2001;19(12):3045-3050

25 Italiano A, Di Mauro I, Rapp J, et al. Clinical effect of molecular methods in sarcoma diagnosis (GENSARC): a prospective, multicentre, observational study. Lancet Oncol 2016;17(4):532-538

26 Coindre JM, Terrier P, Guillou L, et al. Predictive value of grade for metastasis development in the main histologic types of adult soft tissue sarcomas: a study of 1240 patients from the French Federation of Cancer Centers Sarcoma Group. Cancer 2001;91(10):1914-1926

27 ESMO/European Sarcoma Network Working Group. Soft tissue and visceral sarcomas: ESMO Clinical Practice Guidelines for diagnosis, treatment and follow-up. Ann Oncol 2014;25 (Suppl 3) : iii102-iii112

28 Kraybill WG, Harris J, Spiro IJ, et al. Long-term results of a phase 2 study of neoadjuvant chemotherapy and radiotherapy in the management of high-risk, high-grade, soft tissue sarcomas of the extremities and body wall: Radiation Therapy Oncology Group Trial 9514. Cancer 2010;116(19):4613-4621

29 Kuklo TR, Temple HT, Owens BD, et al. Preoperative versus postoperative radiation therapy for soft-tissue sarcomas. Am J Orthop 2005;34(2):75-80

30 Saltus CW, Calingaert B, Candrilli S, et al. Epidemiology of adult soft-tissue sarcomas in Germany. Sarcoma 2018;2018:5671926

31 Savina M, Le Cesne A, Blay JY, et al. Patterns of care and outcomes of patients with METAstatic soft tissue SARComa in a real-life setting: the METASARC observational study. BMC Med 2017;15(1):78

32 van Geel AN, Pastorino U, Jauch KW, et al. Surgical treatment of lung metastases: The European organization for research and treatment of cancer-soft tissue and bone sarcoma group study of 255 patients. Cancer 1996;77(4):675-682 